\section{AL-AZHAR}

Assiut Dental Journal
The Official Publication of The

Faculty of Dental medicine.

Al-Azhar Assiut Uniuersity.

AADJ, Vol. 2, No. 2, October (2019) - PP. 151:161

ISSn 2682-2822

\title{
Evaluation of Fixation Techniques in Anterior Mandibular Fracture Using Three Dimensional Plates versus Conventional Miniplates
}

\author{
Talaat H. Saad ${ }^{* 1}$, Mohammad A. Shuman ${ }^{2}$
}

Codex : 18/1910

Aadj@azhar.edu.eg

\section{KEYWORDS}

Three Dimensional Plate, Anterior Mandibular Fractures, Intermaxillary Fixation, Miniplates, Stability.

1. Department of Oral and Maxillofacial Surgery, Faculty of Dental Medicine, Al-Azhar University, (Cairo, Boys), Egypt.

2. Department of Oral and Maxillofacial Surgery, Faculty of Dental Medicine, Al-Azhar University, Assiut, Egypt.

* Corresponding Author e-mail: talaatsaad123@azhar.edu.eg

\begin{abstract}
Aim : To evaluate the clinical and radiological outcomes of using three dimensional (3D) plates versus conventional miniplates in the management of anterior mandibular fracture.

Subjects and Methods: Twelve patients of both sexes (10 male and 2 female) were selected for this study. The age range from 16-40 with mean age (27.8). All patients were selected with anterior mandible fracture they chosen from those attending outpatient clinic of oral and maxillofical surgery at the faculty of Dental Medicine and at Sayed Galal Hospitals. Results: All patients showed clinical immediately improvement in occlusion and stability of fracture segment after open reduction and fixation except one case in group II need to intramaxillary fixation (IMF). There was statistically insignificant difference between both groups regarding operating time. Conclusion: The findings of this study indicated that 3D titanium miniplates are effective in the treatment of anterior mandibular fractures and overall complication rates are lesser as compared to conventional miniplates. The system is reliable and effective treatment modality for anterior mandibular fractures.
\end{abstract}

\section{INTRODUCTION}

The mandible is the second most commonly fractured bone of the maxillafacial skeleton because of its position and prominence. Although there is wide variance in the reported percentage of fracture of the anterior area of the mandible, aggregate analysis places this at approximately $17 \%$ of all mandibular fractures ${ }^{(\mathbf{1}, \mathbf{2})}$.

Anterior mandibular fractures (AMFs) are defined as: mandibular fractures that involve a region bounded bilaterally by vertical lines just distal to the canine teeth (the parasymphysis) and linear fractures that run in the midline (symphisis) ${ }^{(3)}$.

Miniplate osteosynthesis has become an important fixation mothod in the maxillofacial craniofacial surgery ${ }^{(4,5)}$. It is first induced by 
Michelet (1973) and further developed by Champy in 1975 is today standard for treatment of the mandibular fracture ${ }^{(6)}$. Technical advantage of miniplatc osteosynthesis include small and easily adapted plate, monocortical application, intraoral approach, functional stability and biomechanical favorability. Not only the reduction anatomically acceptable, but the jaw function is also improved, other advantages are patient comfort, improved speech and oral hygiene ${ }^{(7)}$.

Although the concept of bone plating has changed overtime with the introduction of various modifications, such as compression plates, dynamic compression plates, eccentric dynamic compression plates and micro plates, the miniplates are the most commonly used one ${ }^{(8)}$.

The ideal line of osteosynthesis in the mandible where they suggested that miniplate fixation is the most stable ${ }^{(9)}$. According to Champy, tensile forces exist at the superior border of the mandible and compressive forces at its inferior border. Tensile forces exist at the superior border of the mandible due to continuous function of the stomatognathic system which cause distraction at the site. The distraction must be prevented to achieve uniform compression across the length of the fracture ${ }^{(\mathbf{1 0})}$.

Champy et al. advised the use of 2 minplates in the anterior region of the mandible one at the inferior border and the other $5 \mathrm{~mm}$ above the lower plate which may reduce incidence of mental nerve injury and will diminish wound dehiscence ${ }^{(11)}$.

More recently, three dimensional plate 3D has been developed by (Farmand) ${ }^{(12)}$ and became one of the methods of fixation to challenge the Champy technique for the fixation of mandibular fracture with a growing number of the studies ${ }^{(13)}$.

3D plate can be considered a two-plate system with two miniplates joined by interconnecting cross bars ${ }^{(14)}$. The screws are arranged in configuration of a box on both sides of the fracture, a broad band plate form is created, increasing the resistance to twisting and bending of the axis of the plate. These quadrangular plate form a cuboid which possess $3 \mathrm{~d}$ stability ${ }^{(15)}$. The 3D plating system is based upon the principle of obtaining support through geometrically stable configuration. The quadrangle geometry of plate assure a good stability in three dimensional of the fracture site since it offers good resistance against torque forces ${ }^{(16)}$. The thickness can be reduced to $1 \mathrm{~mm}$. The basic form is quadrangular with $2 \times 2$ holes square plate and $3 \times 2$ or $4 \times 2$ hole rectangular plate ${ }^{(17)}$.

Considering this, the purpose of the present study is to evaluate fixation technique in anterior mandibular fracture using 3D plates versus conventional plate.

\section{AIM OF THE WORK}

The aim of the present study was to evaluate the clinical and radiological outcomes of using three dimensional (3D) plates versus conventional miniplates in the management of anterior mandibular fracture.

\section{PATIENTS AND METHODS}

Twelve patients of both sexes (10 male and 2 female) were selected for this study. The age range from 16-40 with mean age (27.8).

All patients were selected with anterior mandible fracture they chosen from those attending outpatient clinic of oral and maxillofical surgery at the faculty of Dental Medicine and at $\mathrm{Al}$ - Azhar University hospitals.

\section{Patients were divided into two groups: Group}

I: 6 patients were treated with 3D miniplates. Group II: 6 Patients were treated with conventional miniplates.

Study setting: It's a clinical consequatively study. 
Inclusion criteria: Patients with fracture of symphysis and parasymphysis region of the mandible. Patients medically fit for surgery under general anesthesia. Patients who have teeth in a good condition on both sides of the fracture line.

Exclusion criteria: Patients with comminuted fracture and pathologic fractures. Any patients who is suffering from any systemic disease affecting the healing condition. Patients with fractured or (mobile anterior teeth). Patients with edentulous mandible. Pediatric patients blew 12 years of age.

Clinical evaluation: History and physical examination to determine the cause of the fracture. All the patients of the present study were assessed preoperatively well as postoperatively through the following:

Clinical examination both extraorally and intraorally: Extraoral and intraoral clinical examinations were performed on all patients. This includes recording the occlusion status, nerve affection, soft tissue injuries, stability of fracture and photographs.

Occlusion: The status of occlusion was recorded according to the ability of the patient to close his/ her mouth in maximum intercuspation and perform efficient mastication. Occlusal status was evaluated by asking the patient to occlude in centric occlusion and then any occlusion abnormalities were recorded.

Nerve affection: Nerve affection was evaluated subjectively by asking the patient and objectively by testing the lip paresthesia by stimulating pain sensation by ditching the lip with a probe.

Soft tissue injuries: Gingival and / or mucosal injuries related to the fracture line were reported.

Stability of fracture: Clinical stability at the fracture site was tested after operation by bimanual manipulation and by asking the patient to open his/ her mouth against moderate pressure applied at the point of the chin via the operator's palm.
Photographic picture: Both intraoral and extraoral photograph were taken for each patient pre operatively as well as postoperatively for comparison of the final outcome.

Radiographic evaluation: PA and panoramic radiographs were taken to define the location, type of fractures, presence of tooth in fracture line, and degree of comminution of the fracture and displacement of the segments. The degree of displacement of the fracture segments was assessed by measuring the gap distance between the segments at the step deformity along the inferior border of the mandible on a digital panoramic radiography (magnification 1: 1) and recorded to be either $0 \mathrm{~mm}$, less than or equals to $2 \mathrm{~mm}$ or more.

All patients were informed by the study and signed a concent form before the surgery.

Operative technique: All patient subjected to general anesthesia by nasal intubation using armored or ordinary nasal tube. Intra oral and extra oral scrubbing was performed using concentrated betadine $10 \%$. Injection of 1/100000 adernaline into the operated area up to $10 \mathrm{ml}$ to aid in homeostasis.

Establishment of occlusion: Arch bars or Ivy loops (according to the case) and intermaxillary fixation (IMF) were used to establish the pre injury relationship of the mandibular and maxiallary teeth.

\section{Open reduction and internal fixation: Surgical} approach: the intra oral mandibular vestibular approach was given by making curvilinear incision that is approximately a centimeter away from the attached gingival to allow enough tissue for a watertight closure at the end of the procedure. Care must be taken to avoid injuring the mental nerve. After incising through the mucosa, mentalis muscle was exposed and incised perpendicular and deep to the bone, leaving a flap of muscle attached to bone for closure. The mentalis muscle is divided and the periosteum was elevate to expose the fracture line enough for placement of the hardware. 


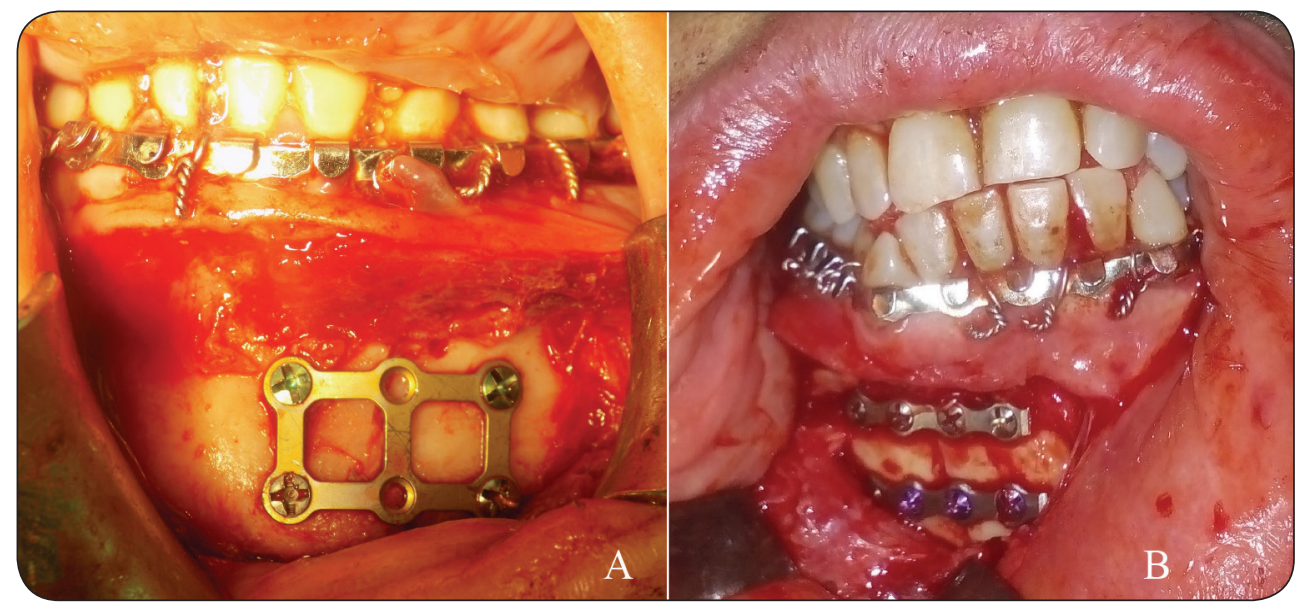

Fig. (1) A) 3D plate was placed at fracture site. B) Conventional plate was placed of fracture site in case 7 .

Reduction and fixation: The fracture fragments were reduced to their anatomical form and jaws were placed temporary into intermaxillary fixation (IMF). The segments were manibulated with mucoperiosteal elevator or reduction forceps.

Once the reduction of the fracture and the maximum intercuspation of teeth were assured: Group I: 3D miniplates were seated over the fracture site, perpendicular to the fracture line and adapted along the outer cortex of the mandible. The interconnecting cross struts of 3D miniplates was placed parallel to the fracture line. The holes were drilled by using a $1.5 \mathrm{~mm}$ diameter drill loaded on power driven micro-motor under copious irrigation with normal saline. Then 3D miniplates were secured with monocortical screws $(2 \mathrm{~mm}$ diameter, $5 \mathrm{~mm}$ or $9 \mathrm{~mm}$ length) by using the screw driver down into the previously prepared holes. Group II: 2 conventional miniplate was placed over the bone surface by using monocortical screw $5 \mathrm{~mm}$ in length placed on the superior border of the mandible and $9 \mathrm{~mm}$ placed on the inferior border of the mandible.

After the procedure was completed, IMF was removed, leaving the arch bars in place and occlusion was checked. The fixed fracture fragments were checked manually to confirm correct anatomical and functional reduction and fixation. Postoperative IMF was not used in any patient.
Closure: The area was irrigated with copious amount of normal saline. Hemostasis was achieved, the deeper layers of the wound was closed in layers with 4-0 vicryl and outer layer was closed with 4-0 silk in a watertight closure of the mucosa is then performed. Adhesive plaster strips maintained 48 hours are used to reapproximate the mental soft tissue over the bony mentum and to minimize oedema.

\section{Postoperative followup:}

Clinical followup: Patients were evaluated clinically at second day, one week, three and six months postoperatively after surgery. Clinical examinations were include the following: Maximal mouth opening: measuring maximal interinciasal opening between maxillary and mandibular central incisors. State of occlusion: the occlusion was checked in maximal intercuspal position (centric occlusion) to ensure proper occlusal relationship including molar relation and midline centralization. Any occlusal disturbances including open bite or improper tooth contact was noted. Occlusion was considered satisfactory when there was no gap in maximum intercuspition relation and the patient can occlude on both sides perfectly and perform normal function. The occlusion considered mild deranged if there was (1-2mm) gap, where it was considered deranged if there was more than $2 \mathrm{~mm}$ gap. Surgical wound: the sutured wounds were examined for 
signs and symptoms of infection including swelling, redness, hotness, discharge, and pain in addition to observation for any manifestations of wound healing disturbance. Suture removal was done at 7 days.

Postoperative followup: Digital panoramic view was taken for each patient at $2^{\text {nd }}$ day, 3 and 6 months,. The status of reduction and alignment of bone segments was observed for each patient. This was assessed using a score from 1 to 3 as descried by Malhorta et a1. ${ }^{(18)}$. Score 3: Radiological evidence of precise anatomic reduction in the fracture site. Score: 2 Reduced fractures that were slightly displaced but had a satisfactory occlusion. Score 1: Poorly reduced fractures that required a second operation to correct the alignment and unacceptable occlusion The higher value was indicated better plating. The obtained radiograms were compared to the preoperative films.

\section{Statistical Analysis}

Data were collected, revised, coded and entered to the Statistical Package for Social Science (IBM SPSS) version 23. The quantitative data were presented as mean, standard deviations and ranges when their distribution found parametric. Also qualitative variables were presented as number and percentages.

The comparison between two independent groups with quantitative data and parametric distribution were done by using Independent t-test. The confidence interval was set to $95 \%$ and the margin of error accepted was set to $5 \%$. So, the p-value was considered significant as the following: P-value $>0.05$ : Non significant (NS). P-value < 0.05: Significant (S). P-value < 0.01: Highly significant (HS)

\section{RESULTS}

Twelve patients were participated in this study (10 male and 2 female). All of them were presented with main suffering from isolated anterior mandibular fractures. Their age ranged from 16 to 40 years old with mean age 27.8 . The period between injury and operation was 4-10 days. Nine patients had parasymphsial fracture $(75 \%)$ and 3 patients had symphsial fracture (25\%).

The diagnosis of anterior mandibular fracture was based on clinical examination and radiographic finding.

Patients were checked to note status soft tissue injury or swelling. However, if the patient was awake and cooperative, patient was questioned about the presence and location of pain, malocclusion, trismus, intraoral bleeding, and loss of sensation, particularly in the mental nerve region. When examining the patient, the general appearance was first assessed and any lacerations, ecchymoses, edema, or areas of distortion were noted. The entire mandible was palpated for tender areas and mobility.

None of the patients showed any local or systemic complication related to the procedure treatment of the fracture.

Patients divided into two groups: Group I: 6 patients treated by 3 d miniplate. Group II: 6 patients treated by conventional miniplate.

A satisfactory reduction, fixation and occlusion were achieved in all patient. All cases were followedup over six months followup period. During the six months of followup period non of them was missing. None of the patients had plate fracture, non union or loosening of plate and screw within the followup period.

\section{Intraoperative evaluation}

Operative time: The operation time from the beginning incision to soft tissue closure was recorded in minute for every patients in both groups. The duration of surgery in group I ranged from (40 min to $44 \mathrm{~min}$ ) with a mean of $41.69 \mathrm{~min}$. The duration of surgery in group II ranged from (52min. to $57 \mathrm{~min}$.) with mean of $54.5 \mathrm{~min}$. There was statistically significant difference between both groups regarding operating time. 
Table (1) Frequency of operating time of both groups.

\begin{tabular}{|c|c|c|c|c|}
\hline \multirow{2}{*}{$\begin{array}{c}\text { Operation } \\
\text { time }\end{array}$} & 3D plate & $\begin{array}{c}\text { Conventional } \\
\text { miniplate }\end{array}$ & $\begin{array}{c}\text { Test } \\
\text { value }\end{array}$ & P-value \\
\cline { 2 - 4 } & No. $=\mathbf{6}$ & No. = 6 & \\
\hline Mean \pm SD & $\begin{array}{c}41.67 \pm \\
1.63\end{array}$ & $54.50 \pm 1.87$ & \multirow{2}{*}{$-12.659 \bullet$} & 0.000 \\
\hline Range & $40-44$ & $52-57$ & & \\
\hline
\end{tabular}

$P$-value $>0.05$ : Non significant (NS);

$P$-value $<0.05$ : Significant $(S)$;

$P$-value $<0.01$ : highly significant $(H S)$

$\because$ Independent t-test

\section{Postoperative results}

\section{A-Clinical outcomes}

Occlusion stability: Patients showed clinical improvement in occlusion immediately after operation. Asatisfying occlusion was observed in 9 patients $(75 \%)$ however $25 \%$ of the patients had minor postoperative occlusal disturbance which needed correction by grinding of the teeth was performed in 3 patients due to premature contact. $2^{\text {nd }}$ day postoperatively: 5 patients had abnormal occlusion group I: 2 patients mild deranged (33.3\%) group II: 1 patient deranged (16.7\%), 2 patients mild deranged (33.3\%). First week: 3 patients had abnormal occlusion group I: 1 patient mild deranged (16.7\%). Group II: 2 patients mild deranged (33.3\%). 3 patients need grinding of high spot. 3 weeks: one patient still mild deranged $(16.7 \%)$ in group II. Satisfactory occlusion at 6 weeks, 3 months and 6 months.

Mouth opening: Using one way ANOVA test the results showed that gradual improvement in mouth opening. $2^{\text {nd }}$ day postoperatively maximum mouth opening in both groups was limited with a mean $25 \mathrm{~mm}$. 1 week measurement of maximum mouth opening was enhanced mean $32 \mathrm{~mm}$. 3 weeks measurement of mouth opening was satisfactory increased mean $(41.2 \mathrm{~mm})$ in group I but in group II not increased. After 3 and 6 months no significant increase between 3 and 6 months postoperative.
Stability of the fracture: All patients showed clinical immediately improvement in stability of fracture segment after open reduction and fixation except one case in group II need to intramaxillary fixation (IMF). All patients in group I showed stability of fracture segment immediately after surgery and throughout all followup periods but in group II 2 patients (33.3\%) showed little stability but digital manipulation 1 patient need arch bar, elastic and $2^{\text {nd }}$ patient need IMF for due to eating of the patient hard diet.

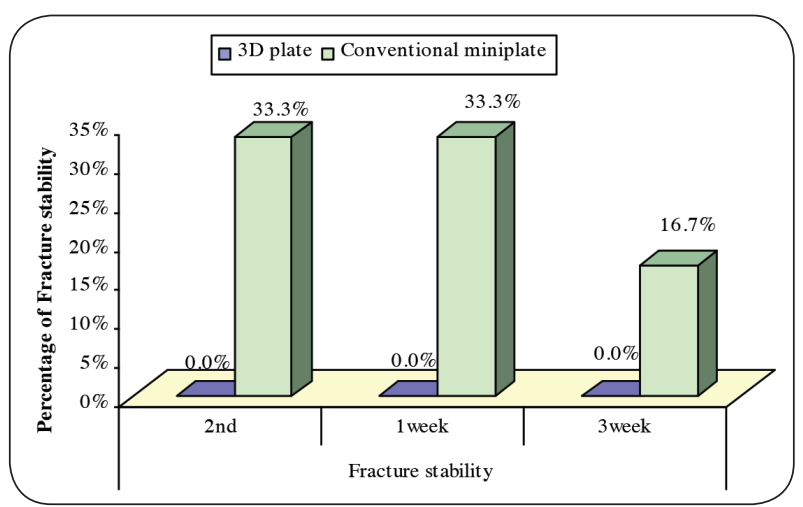

Fig. (2) Bar chart showing stability of the fracture in the both groups throughout followup intervals.

\section{B- Radiographic results}

Immediate postoperative radiological evaluation: All immediate postoperative digital panoramic radiographs had taken within the first two days, radiographs showed good reduction in both groups, with alignment of the osseous borders of the mandible and accepted anatomical reduction with absence of any feature of fixation failure such as screw loosening or plate fracture.

Evaluation of radiogical finding after three and six months postoperatively: Postoperative digital panoramic radiographs were taken after three and six months respectively showed good reduction in both groups, with alignment of the osseous borders of the mandible, when crossed by the fracture line. 

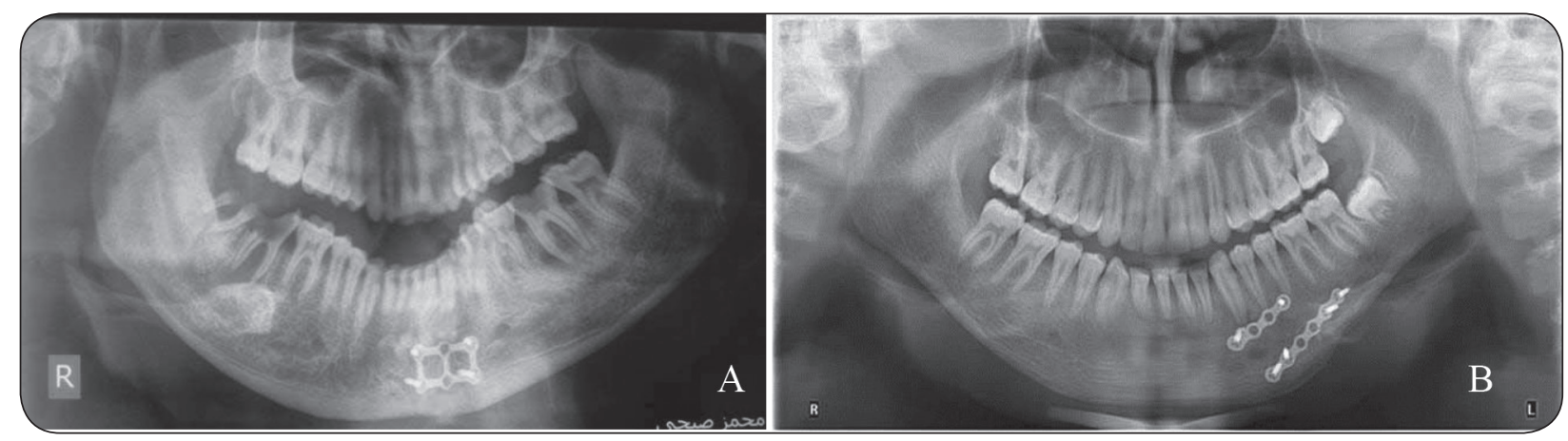

Fig. (3) A) Panoramic view showing conventional plate after six months in group I. B) Panoramic view showing conventional plate after six months in group II.

Proper alignment: Fixation was successful and maintains adequate alignment of fractured segment in both groups during whole postoperative periods fracture line could not be noticed.

Screw lossening: No screw loosening was observed in both groups.

Plate fracture: All cases showed no plate fracture.

Nonunion: All Cases showed no nonunion.

\section{DISCUSSION}

In the present study, we found that 3D titanium minipaltes were effective in the treatment of anterior mandibular fractures and overall complication rates were lesser.

The use of 3D plating system in various procedures of maxillofacial region needs to be explored. The basic concept of 3D fixation as explained by farmand is that a geometrically closed quadrangular plate secured with bone screws creates stability in there dimensions. The stability is gained over a defined surface area and is achieved by its configuration and not by its thickness or length. The large free areas between the plate arms with minimal dissection permit good blood supply to the bone. ${ }^{(19)}$

In this study all patients were treated through an intraoral approach. This is supported by the study of Kruger and Schilli ${ }^{(20)}$ Nishioka and van Sickers ${ }^{(21)}$ who stated that intraoral approach is preferable for open reduction of mandibular fracture. Its advantage are: adequate access for inspecting the occlusion at all times, lesser change of the facial nerve damage and better esthetics due to avoidance of extraoral scar.

During the surgical procedure two parameters were recorded the degree of stability of fracture segment after fixation and operation time needed to establish the whole surgical procedures from incision till the closured wound.

Regarding the preoperatiove status of occlusion, nine patients $75.0 \%$ ) showed abnormal occlusion, while three patients (25.0\%) showed normal occlusion. Second day postoperatively 1 patients $(16.7 \%)$ in group I and 2 patients (33.3\%) in group II had abnormal occlusion. The same result was reported at 1 week and 3 week. This 3 patients with slightly abnormal occlusion needed grinding of high spots to get proper occlusion. Results of the current study is in accordance with that of Venugopal MG et al. ${ }^{(22)}$ who found abnormal occlusion postoperatively. Ellis (23) showed postoperative malocclusions in approximately $6 \%$ of the cases who were managed simply by occlusal adjustment. The same result was found by Kuriakose et al. ${ }^{(24)}$ and Tuovinen et al. ${ }^{(25)}$ in managing this complication. Zachariades $\mathrm{N}$ et al. ${ }^{(26)}$ who reported malocclusion in (3\%) of cases. Renton and Wiesenfeld ${ }^{(27)}$ in their study reported that; cases treated with titanium plate fixation and mouth opened immediately after surgery. 
The result of this study regarding occlusion was highly significant by the end of followup periods. This is because of the box like configuration of the 3D miniplate which provide semi rigid fixation of the fracture and prevent buccolingual splaying and gap formation at fracture site. Results of the current study coincide with that of Bipin and Sonal ${ }^{(28)}$ and Kumer et al. ${ }^{(29)}$ Results of the present study revealed that the pre operative parasthesia of lower lip occurred in $(25.0 \%)$ of patients as result of the accident. After reduction and fixation of the fracture the percentage of patients affected with parasthesia in creased to $(41.7 \%)$.

Fracture reduction could damage the nerve by manipulation of fractured fragments or cloud be caused by stretching the nerve due to extensive lip retraction. 3 weeks postoperatively the percentage of patient with parasthesia decreased to (25\%). At 6 weeks the percentage decreased $(16.7 \%)$, at 3 months postoperatively the percentage decreased to $(8.3 \%)$, at six months postoperatively no patient in both groups reported parasthesia. There was no statistically significant different between both groups.

Regarding to the maximal mouth opening all patients had inadequate mouth opening on the immediate post operative day (mean $25 \mathrm{~mm}$ ).

It may be attributed to post operative edema and trauma itself by the end of first week, results of repeated measure anova showed that the maximum mouth opening showed significant increased starting from $1^{\text {st }}$ week postoperative till $3^{\text {rd }}$ month.

This improvement is attributed to good reestablishment of pre injury state of occlusion and physical training after surgery, while there has been no significant increase between the $3^{\text {rd }}$ and $6^{\text {th }}$ month.

Regarding the stability of the fracture segment, both the systems have adequate stability after fixation of fracture. The stability of 3D plate is gained over a defined surface area and is achieved by its configuration and not by thickness or length. The large free areas between the plate arms and minimal dissection permit good blood supply to the bone. The 3D system is easy to use and cost effective. Further it uses lesser hardware as compared to conventional miniplates. Clinical stability of the fractured segment in term of imobility or no mobility at the fracture site was tested after operation for both groups except (one patient in group II) need to IMF due to slight mobility after operation due to ignorance of instruction postoperatively.

This result is similar to study done by Bipin and Sonal ${ }^{(28)}$ as they found mobility of fractured segments in 2 patients treated with conventional miniplate but it dose agree with their results regarding 3D miniplate.

As they found none of the patients treated with 3D miniplate had mobility of fractured segments also, these results are in disagreement with that of Brad et al. ${ }^{(30)}$ who found mobility of the fractured segments in patients treated by conventional and 3D miniplate.

Regarding to radiographic results immediate postoperative radiological evaluation: panoramic radiograph showed good reduction in both groups with alignment of osseous borders of the mandible due to the proper application of intraoperative IMF and the proper placement of the bone plate. These results were highly significant at all post operative period in our study. A result of this study is in accordance with study of Jain et al. ${ }^{(31)}$ Malhort et al. ${ }^{(18)}$ and Khalifa et al. ${ }^{(32)}$.

Hardware failure; in the present study, the hardware failure (in form of plate fracture or screw loosening) was observed radiogrphically till $12^{\text {th }}$ week postoperatively. It was $0 \%$ due to good adaptation of the plate on the bone (low thickness profile and maliable), quadrangular configuration of the plate and secured interfragmentary reduction of the fractured bone segments. Other studies were similar, i.e. $0 \%{ }^{(33)}$ Whereas Zix et al. ${ }^{(34)}$ reported a hardware failure of $5.8 \%$. The reason for the hardware failure most likely lies in the reduced 
inter fragmentary cross sectional bone surface at the fracture site.

Evaluation of radiographic finding after 3 and 6 month postoperatively showed, proper alignment of osseous border no screw loosening, no fracture plate, no malunion and no nunion in both groups.

\section{CONCLUSION}

The findings of this study indicated that 3D titanium miniplates are effective in the treatment of anterior mandibular fractures and overall complication rates are lesser as compared to conventional miniplates. The system is reliable and effective treatment modality for anterior mandibular fractures.

It can be concluded that: 3D plate can be used as an alternative to conventional miniplates. Fixation of mandibular fractures with 3D miniplate provides 3D stability, stable occlusion and have no deleterious effect on the healing of soft tissue wounds. The 3D plate is effective and its use significantly reduces the operating time and therefore the time of anesthesia. Also the advantages of $3 \mathrm{D}$ there is limitation to use in cases of oblique fracture and those involving the mental nerve. But conventional miniplate used in oblique fracture that include mental nerve. A larger sample size however may be required to substantiate the present results.

\section{REFERENCES}

1. Brown J, Grew N, Taylor C, Millar B. Intermaxillary fixation compared to miniplate osteosynthesis in the management of the fractured mandible: an audit. Br J Oral Maxillofac Surg 1991; 29: 308-311.

2. Cawood J. Small plate osteosynthesis of mandibular fractures. Br J Oral Maxillofac Surg 1985; 23: 77-91.

3. Dingman R, Natvig P. Surgery of facial fractures. Philadelphia, PA. WB Saunders, 1964.

4. Champy M, Pape H, Gerlach K, Loddi V. The Strasbourg miniplates osteosynthesis. In: Oral and maxillofacial traumatology, Vol II, Quintessence, 1986; Chicago.
5. Evans E, Thomas I. The in vitro toxicity of cobalt-chromemolybdenum alloy and its constituent metals. Biomaterials 1986; 7: 25-29.

6. Sadhwani B, Anchlia S. Conventional $2.0 \mathrm{~mm}$ miniplates versus 3- D plates in mandibular fractures. Ann Maxillofac Surg 2013; 3: 154- 159.

7. Sehgal S, Ramanujam L, Prasad K, Krishnappa R. Threedimensional $\mathrm{v} / \mathrm{s}$ standard titanium miniplate fixation in the management of mandibular fractures-a randomized clinical study. J Craniomaxillofac Surg 2014; 42: 1292-1299.

8. Feller K, Richter G, Schneider M, Eckelt U. Combination of microplate and miniplate for osteosynthesis of mandibular fractures: an experimental study. Int $\mathrm{J}$ Oral Maxillofac Surg 2002; 31: 78-83.

9. Saluja H, Kini Y, Mahindra U, Kharkar V, Rudagi B, A comparative evaluation of different treatment modalities for parasymphysis fractures: a pilot study. Int $\mathrm{J}$ Oral Maxillofac Surg 2012; 41: 906-911.

10. Champy M, Lodde J, Schmitt R, Jaeger J, Muster D. Mandibular osteosynthesis by miniature screwed plates via a buccal approach. J Maxillofac Surg 1978; 6: 14-21.

11. Ellis E. 3rd A study of 2 bone plating methods for fractures of the mandibular symphysis/body. J Oral Maxillofac Surg 2011; 69: 1978-1987.

12. Farmand M, Dupoirieux L. [The value of 3-dimensional plates in maxillofacial surgery]. Rev Stomatol Chir Maxillofac 1992; 93: 353-357.

13. Al-Moraissi E, Ellis E. Surgical management of anterior mandibular fractures: a systematic review and metaanalysis. J Oral Maxillofac Surg 2014; 72: 2507-2511.

14. Kalfarentzos E, Deligianni D, Mitros G, Tyllianakis M. Biomechanical evaluation of plating techniques for fixing mandibular angle fractures: the introduction of a new 3D plate approach. Oral Maxillofac Surg 2009; 13: 139-144.

15. Guimond C, Johnson J, Marchena J. Fixation of mandibular angle fractures with a 2.0-mm 3-dimensional curved angle strut plate. J Oral Maxillofac Surg 2005; 63: 209-214.

16. Vineeth K, Lalitha R, Prasad K, Ranganath K, Shwetha V. "A comparative evaluation between single noncompression titanium miniplate and three dimensional titanium miniplate in treatment of mandibular angle fracture" a randomized prospective study. J Craniomaxillofac Surg 2013; 41: 103-109.

17. AI-Moraissi E, El-Sharkawy T, EI-Ghareeb T. Comparison between three-dimensional versus standard miniplate 
fixation in the management of mandibular angle fractures: a systematic review and meta-analysis. Int J Oral Maxillofac Surg 2014; 43: 708-716.

18. Malhotra K, Sharma A, Giraddi G, Shahi AK. Versatility of titanium 3D plate in comparison with conventional titanium miniplate fixation for the management of mandibular fracture. Journal of maxillofacial and oral surgery. 2012; 11(3):284-90

19. Meyer C, Serhir L, Boutemi P. Experimental evaluation of three osteosynthesis devices used for stabilizing condylar fractures of the mandible. Journal of Cranio-Maxillofacial Surgery. 2006; 34(3):173-81.

20. Kruger E and Schilli W. Quintessence publishing co Inc; Oral and Maxillofacial Traumatology 1982; 1 38, 39, 309, 312.

21. Nishioka GJ, Van Sickels JE. Transoral plating of mandibular angle fractures: A technique. Oral surgery, oral medicine, oral pathology. 1988; 66(5):531-5.

22. Venugopal MG, Sinha R, Menon PS, Chattopadhyay PK, Chowdhury SR. Fractures in the maxillofacial region: A four year retrospective study. Medical Journal Armed Forces India. 2010; 66(1):14-7.

23. Ellis E, Miles BA. Fractures of the mandible: a technical perspective. Plastic and reconstructive surgery. 2007; 120(7):76S-89S

24. Kuriakose MA, Fardy M, Sirikumara M, Patton DW, Sugar AW. A comparative review of 266 mandibular fractures with internal fixation using rigid (AO/ASIF) plates or mini-plates. British journal of oral and maxillofacial surgery. 1996; 34(4):315-21.

25. Tuovinen V, Nørholt SE, Sindet-Pedersen S, Jensen J. A retrospective analysis of 279 patients with isolated mandibular fractures treated with titanium miniplates. Journal of oral and maxillofacial surgery. 1994;52(9):931-5.

26. Zachariades N, Mezitis M, Rallis G. An audit of mandibular fractures treated by intermaxillary fixation, intraosse- ous wiring and compression plating. British Journal of Oral and Maxillofacial Surgery. 1996; 34(4):293-7.

27. Renton TF, Wiesenfeld D. Mandibular fracture osteosynthesis: a comparison of three techniques. British Journal of Oral and Maxillofacial Surgery. 1996; 34:166-73.

28. Bipin S and Sonal A. "Conventional $2.0 \mathrm{~mm}$ miniplates versus 3-D plates in mandibular fractures." Annals of maxillofacial surgery. 2013;3(2): 154.

29. Kumar BP, Kumar J, Mohan AP, Venkatesh V, Kumar HR. A comparative study of three dimensional stainless steel plate versus stainless steel miniplate in the management of mandibular parasymphysis fracture. J Bio Innov. 2012; 1(2):19-32.

30. Barde DH, Mudhol A, Ali FM, Madan RS, Kar S, Ustaad F. Efficacy of 3-dimensional plates over Champys miniplates in mandibular anterior fractures. Journal of international oral health: JIOH. 2014; 6(1):20

31. Jain MK, Sankar K, Ramesh C, Bhatta R. Management of mandibular interforaminal fractures using 3 dimensional locking and standard titanium miniplates-A comparative preliminary report of 10 cases. Journal of CranioMaxillofacial Surgery. 2012; 40(8): 475-8.

32. Khalifa ME, El-Hawary HE, Hussein MM. Titanium three dimensional miniplate versus conventional titanium miniplate in fixation of anterior mandibular fractures. Life Sci J. 2012; 9(2):1006-10.

33. Mano JK, Manjunath KS, Bhagwan BK, Shah DK. Comparison of 3-dimensional and standard miniplate fixation in the management of mandibular fractures. Journal of Oral and Maxillofacial Surgery. 2010; 68(7):1568-72.

34. Zixe J, Olivier L, Tateyuki I. Use of straight and cure 3 dimesional titanium miniplates for fracture fixation at the mandibular angel. J Oral Maxillofac. USurg 2007; 65: 1758-1763. 


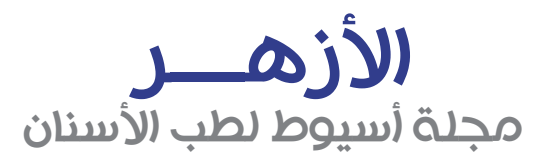

النشر الرسمي لكلية طب الأسنان

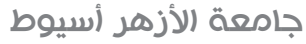

\title{
تقييم استخدام الشرائح الصغيره ثلاثيه الإبعاد بالمقارنة للشرائح

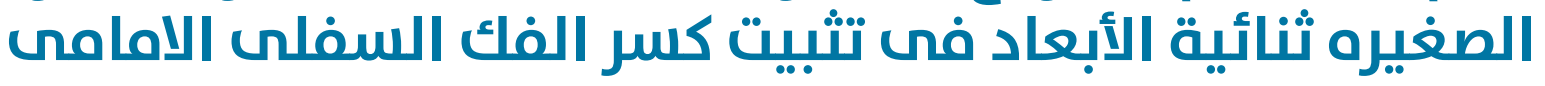

\author{
طلعت حماده سعد 1*, محمد عبدالحميد شومان 2 \\ 1 قسم جراحة الفم والوجه وافكين, كلية طب الاسنان, جامعة الازهر, ( القّاهره, بنين), هصر \\ 2 قسم جراحة الفم والوجه وافكين, كلية طب الاسنان, جامعة الازهر , اسيوط, مصر \\ TALAATSAAD123@AZHAR.EDU.EG البريد الالكترونى **
}

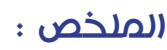

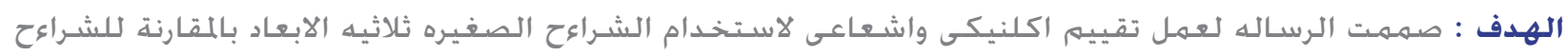

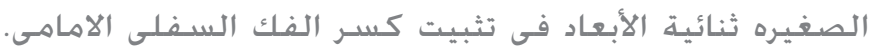

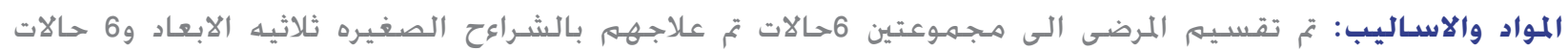

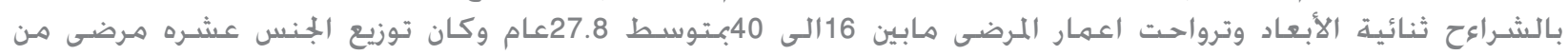

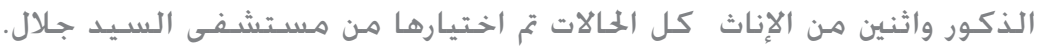

النتائج: كل الحالات تتحسـن تدريجيا اكلنيكا واشعاعيا خاصه في الاطباق وثبات الكسـروله يكن هناك دلاله احصائيه

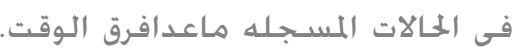

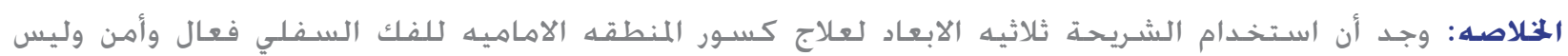

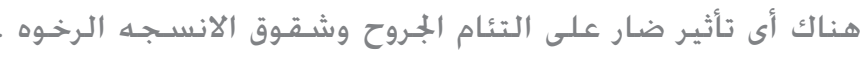

الكلمات المفتاحيه: شـريحهـ ثلاثية الابعاد، كسـور الفك السفلى الاماميه، التثبيت بين الفكين، شـريحهـ دقيقه، الثبات

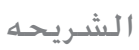

